\title{
Silicate karst associated with lateritic formations (examples from eastern Niger)
}

\author{
B. Sponholz \\ Geographisches Institut, Universität Würzburg, Am Hubland, D-97074 Würzburg, Germany
}

\begin{abstract}
Silicate and iron crust karst pits and sinkholes in eastern Niger are filled with reworked lateritic sediments or with unconsolidated palaeosoils and aeolian deposits. The fillings facies depend on the environmental conditions during deposition. Geomorphological and sedimentological studies on the karst fillings and the interpretation of various karst/filling associations allow an approach to the chronology of landscape development in eastern Niger plateaus.
\end{abstract}

\section{Introduction}

In eastern Niger, silicate karst features are common in sandstone and iron crust plateaus and may reach as much as 3 vol.\%. Most of the karst was formed during early Tertiary or even Upper Cretaceous times (Sponholz, 1989). The karst forms accessible today have been truncated and thereby fossilized during the formation of valleys and cuestas toward the end of the Tertiary (Faure, 1966; Busche, 1982). Today the karst is partly sediment-filled. The succession and combination of various types of fillings depend on the environmental conditions during deposition and on their later transformation. In this paper, karst-and-filling combinations are presented and interpreted in an approach towards reconstructing the landscape development. The paper will concentrate on the lateritic element in the different fillings.

The term "karst" is used in the same sense as in the former studies by the author on sandstone and iron crust karst as a solution model (Sponholz, 1989). Following the classification by Silvestru (1990), the term "parakarst" (on residual/detritic rocks) would also fit.

\section{The study area}

The study area is situated in eastern Niger between $9^{\circ} \mathrm{E}$ and $15^{\circ} \mathrm{E}$ and between $13^{\circ} \mathrm{N}$ 


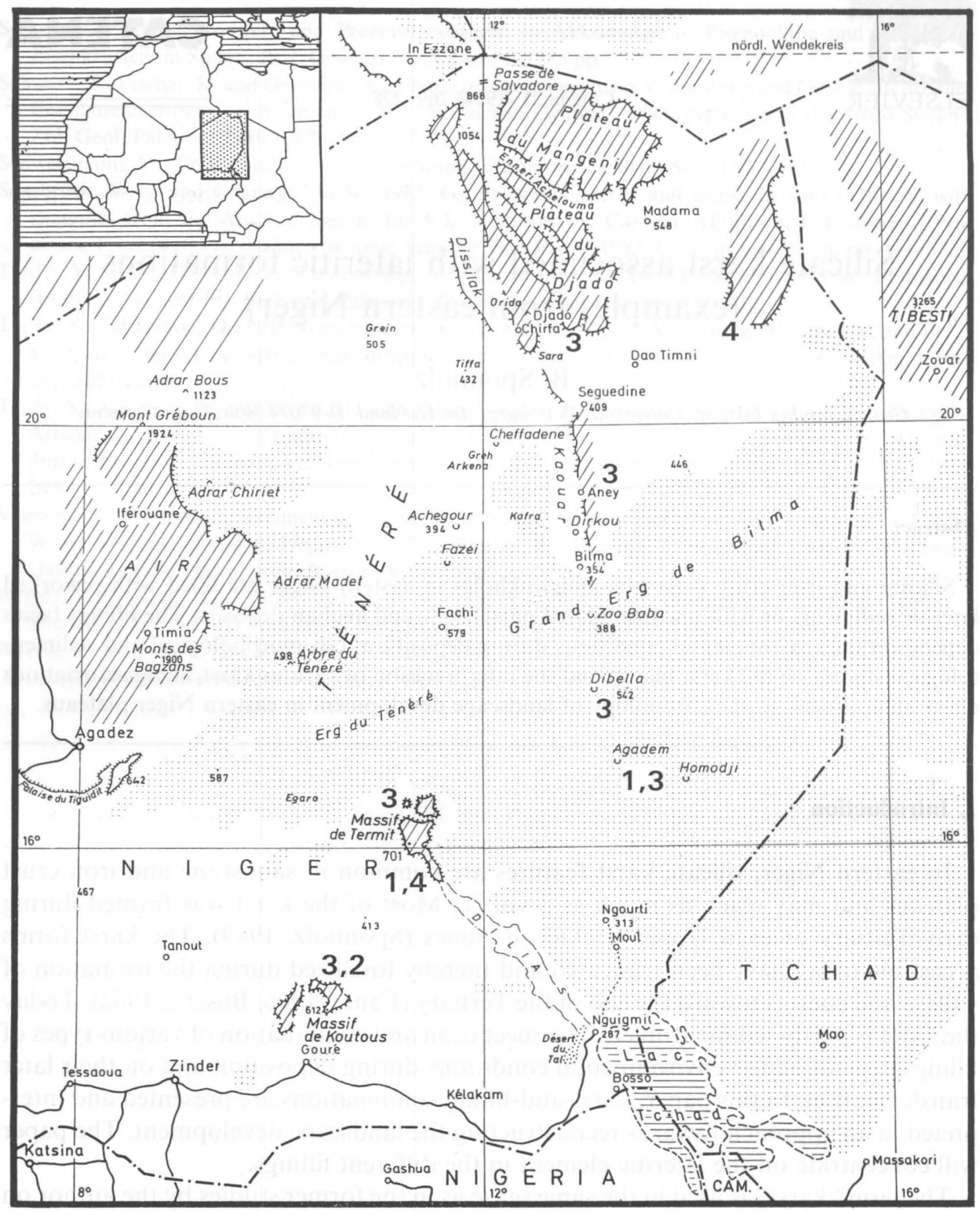

Source: Carte de la Rèpublique du Niger $1: 2,5$ Mill, IGN Paris, Carte Michelin 153, 1 : 4Mill.

Fig. 1. The study area in eastern Niger. The localization of features mentioned in the text is given by numbers. (1) Karst pits in iron crusts with lateritic/non-lateritic fillings (see 4.1). (2) Sandstone karst pits with lateritic fillings (see 4.2). (3) Karst depressions in sandstones/iron crusts with unconsolidated fillings (see 4.4). (4) Ferruginous stalactites in sandstone and iron crust karst tubes (see 4.3). 
and $21^{\circ} 30^{\prime} \mathrm{N}$ (Fig. 1). The study sites represent both today's Saharan desert landscape and the semiarid Sahel. The annual rainfall is less than $20 \mathrm{~mm}$ in the north (Bilma: $19.8 \mathrm{~mm} / \mathrm{y}$ ), rising up to about $450 \mathrm{~mm}$ in the south (Zinder: $487.5 \mathrm{~mm} / \mathrm{y}$; Annuaire Meteorologique du Niger), concentrated during the rainy season from July to September.

Most of northeastern Niger is characterized by broad sand sheets, covered by trade-wind oriented longitudinal dunes in the Erg of Ténéré and the Great Erg of Bilma. The wide plains are punctuated by a few isolated plateaus and mesas formed by sandstones and iron crusts. Farther to the south they become increasingly choked by fossil, Pleistocene dune complexes with increasing soil and vegetation cover.

The silicate karst is best developed in the sandstone plateaus belonging to the "Continental intercalaire" ("CI", e.g. the Bilma escarpment), but in the plateaus of Agadem and Termit ("Continental terminal", "CT") as well as in the Koutous plateau region ("Continental hamadien", "CH"; stratigraphical terms after Faure, 1966), well developed karst features exist in iron crusts as well, and they are also associated with lateritic formations.

\section{Methods}

In the field, the geomorphological situation of each site was documented and samples of the unconsolidated fillings were taken down to a maximum depth of $1.20 \mathrm{~m}$, either by layer/horizon differences or at $10 \mathrm{~cm}$ intervals. Samples of breccia fillings (cf. 4.1) and those from the karst hollows walls were taken at surface level.

The rocky materials (karst hollow wall fragments and breccia fillings) were studied as thin-sections and by X-ray analysis of powder preparations [Philips; Co- $K_{\alpha^{-}}$ radiation, $\left.2-50^{\circ}(2 \theta)\right]$.

The unconsolidated fillings were analyzed for:

granulometry: wet sieving (fractions $50-<2000 \mu \mathrm{m})$ and sedigraph analysis $(<50$ $\mu \mathrm{m}$ ); morphoscopy of quartz grains (fraction 100-500 $\mu \mathrm{m}$ diameter) following removal of iron coatings by oxalic acid treatment (after Müller, 1967), magnification upto $\times 50$ (after Cailleux and Tricart, 1963); clay mineral content: X-ray-diffraction analysis $\left[2-30^{\circ}(2 \theta), \mathrm{Co}-K_{\alpha}\right.$-radiation] on $\mathrm{Mg}$-saturated, glycerol-saturated and heated $\left(4 \mathrm{~h}\right.$ at $\left.550^{\circ} \mathrm{C}\right)$ texture preparations; bulk sample mineral content: X-raydiffraction analysis of powder preparations (s.a.); organic matter content (colorimetric), carbonate content (ANNE method), $\mathrm{pH}$ (glass electrode).

\section{Association types of silicate karst and lateritic formations}

The silicate karst features that are developed in quartzitic sandstones and iron crusts of the Saharan plateaus include all dissolution forms that are known from limestone karst elsewhere (Renault, 1953; Busche, 1982; Busche and Erbe, 1987; Sponholz, 1989). The various karst-and-filling combinations allow a preliminary approach to the chronology of landscape formation (cf. Table 1). 
Table 1

Chronology of silicate and iron crust karst formation and of its filling. Q: Quaternary; T: Tertiary; C: Cretaceous; CT: Continental terminal; $\mathrm{CH}$ : Continental hamadien; CI: Continental intercalaire

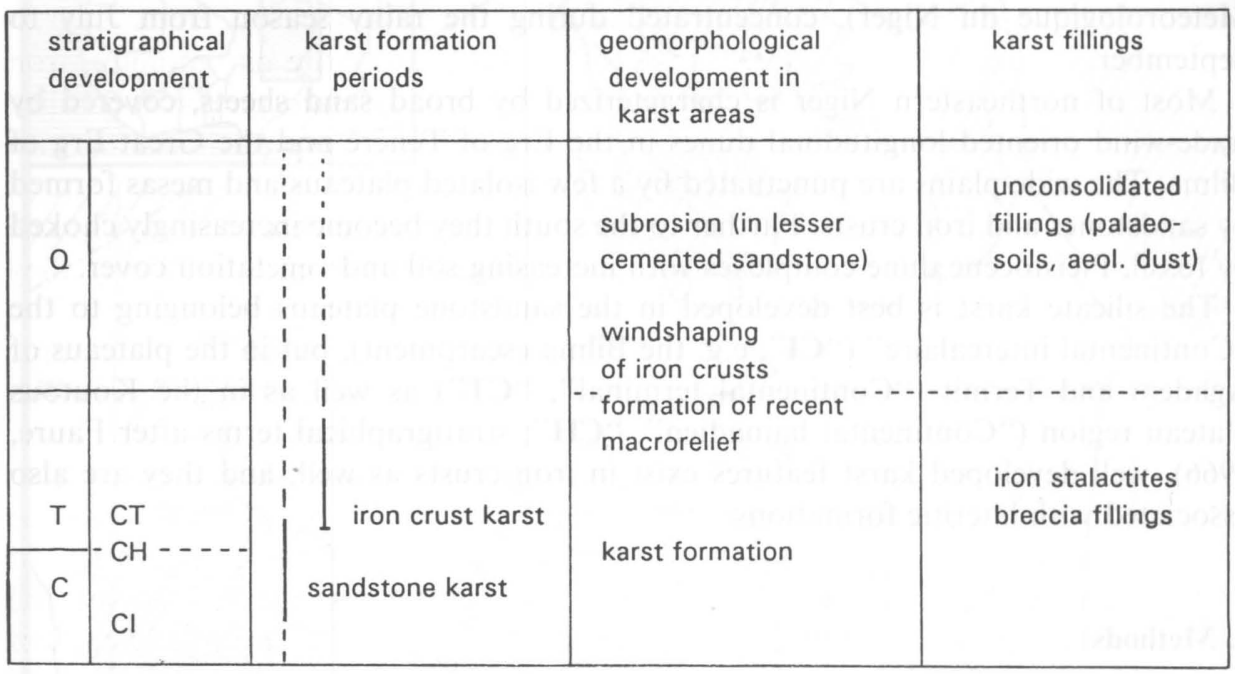

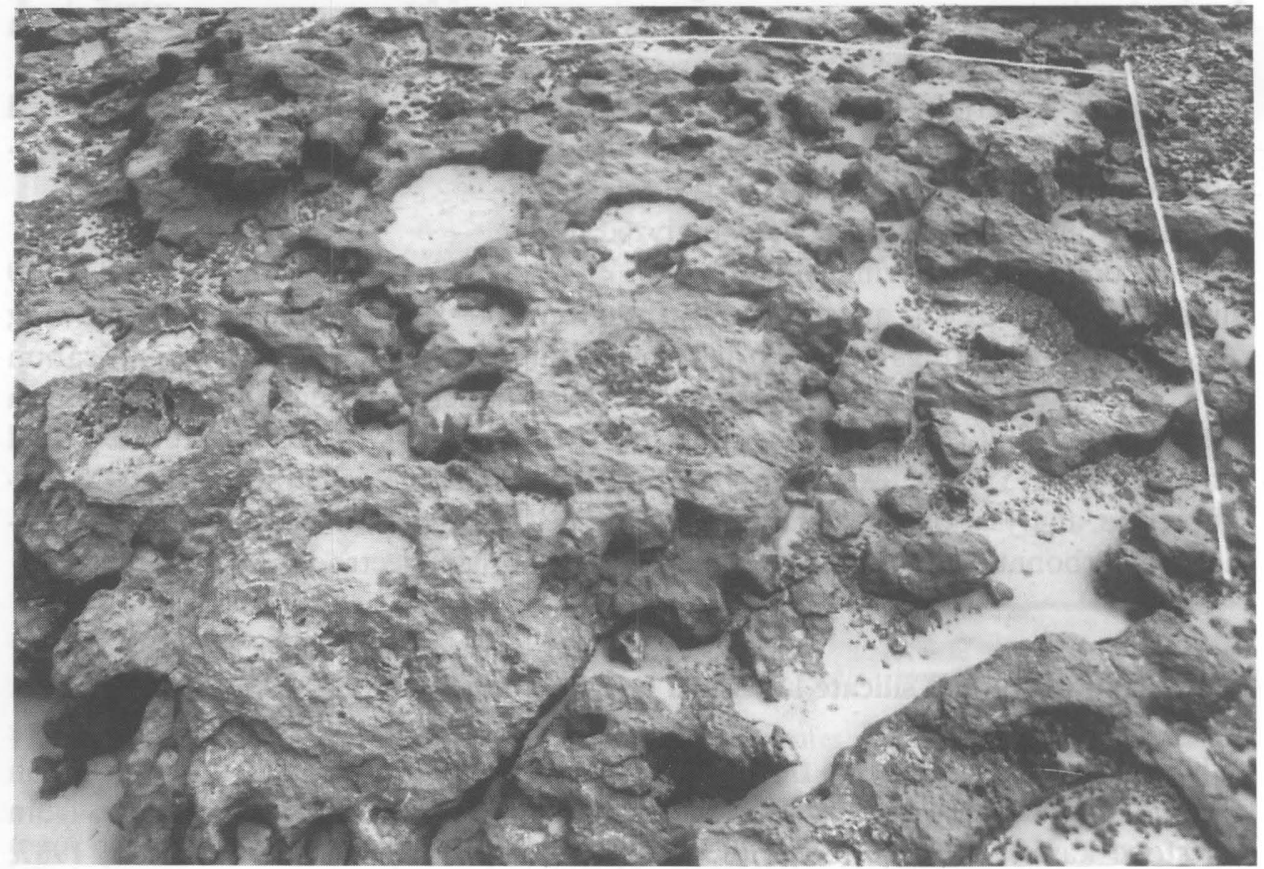

Fig. 2. Vertical solution pits in iron crusts (Termit massif, Continental terminal). The pits are filled with unconsolidated palaeosoils or aeolian dust deposits. (Scale: $2 \times 2 \mathrm{~m}$ ) 


\subsection{Karst pits in iron crusts with lateritic/non-lateritic fillings}

On the plateaus of Termit and Agadem there exist steep-walled karst pits in sedimentary iron crusts of the CT (Fig. 2). The iron crust facies is either quartzsandstone/siltstone in a ferruginous matrix (goethite, haematite or limonite), iron crust clastics and pisoids in a ferruginous matrix, or even amorphous iron-silica deposists. The pits are filled with reworked lateritic, breccia-type material or with unconsolidated palaeosoils and aeolian dust accumulations.

The pits are similar to those at the top of the mottled zone described by Twidale (1987). They are deeper, however ( $>70 \mathrm{~cm}$; with diameters from 5 to $20 \mathrm{~cm})$, they branch out, and the formerly overlying soils have been completely eroded. The karstified lateritic formations in Australia are dated as early Tertiary - the same age as that given for the Saharan and Sahelian iron-rich sediments of the CT (Faure, 1966). The iron crust karst may therefore be regarded as an extreme form of lateritic weathering during the early Tertiary. As the pits are found only in the most indurated iron crusts, their formation as "crabholes" (Upton, 1983) by subrosion can be excluded. Later induration can also be excluded because of the conservation of solution details on the pit walls. Following karstification by solution, however, the shaping of many of the sinkholes was completed by subrosion in underlying, less cemented sandstones (e.g. in the Termit plateau). Subrosion must have occured after the development of the escarpments at the end of the Tertiary (Faure, 1966; Busche, 1982), corresponding to the lowering of the groundwater table (Bowden, 1980).

Some of the pits contain an iron-cemented breccia of clastics that may include all the types of $\mathbf{C T}$ iron crust mentioned above. In thin section this breccia appears as a facies of "low-level laterites" (Hamilton, 1964) resulting from the reworking of laterites and their deposition in poorly-drained basins.

Unconsolidated fillings commonly occur side by side with the brecciated ones. Often they consist of reddish palaeosoils or soil sediments (2,5 YR 5/6 to 7,5 YR 6/6, dry; Munsell Soil Colour Chart) overlain by aeolian dust and sand (10 YR 7/4). Clay mineral content varies from mainly kaolinitic [peak at $d(001)=7.15 \AA$ ] to smectite/illite composition $[d(001)=12-15 \mathrm{~A}$ resp. $10 \AA]$. The sand grains become more wind-shaped toward the top (well-rounded grains: $\approx 3 \%$ in the deeper layers, $\approx 25 \%$ at the top).

\subsection{Sandstone karst pits with lateritic fillings}

In the Koutous plateau $(\mathbf{C H})$, some karst pits in sandstones (silicified layers at the top of ferruginous and kaolinized sandstones) contain the same ferrugineous breccia as described in Section 4.1, corresponding to the CT iron crust facies or to the reworked lateritic sediments.

The contact between the sandstone pits and the brecciated fillings is very sharp: in thin section the sandstone shows increased quartz corrosion near the surface covered by a fine surface layer of amorphous silica, similar to that found on sandstone karst surfaces in CI areas (Sponholz, 1989). There is no interfingering of the lateritic breccia 
fillings with the sandstone. The pits must therefore have already existed in their present shapes at the time of iron breccia deposition. The pits became buried and fossilized by the sediment without further modification. As there are no CT beds in the surroundings of the karst pits, their filling with CT-derived sediment must have taken place before the formation of the present macro-relief, i.e. before the denudation of a formerly existing CT cover, and thus before the end of the Tertiary (cf. Table 1).

\subsection{Sinkholes and uvalas in sandstones and iron crusts with unconsolidated fillings}

Karst depressions (sinkhole or uvala type, up to 200 m diameter) are common on the Termit and Agadem plateaus (Fig. 3). They are situated in the CT sediments (facies cf. 4.1) and contain Quaternary unconsolidated palaeosoils and sediments. Their irregular shapes are often similar to the "ramose sinkholes" shown by Twidale (1987). Underneath the fillings the rock surface at the depression rims is heavily windscoured, indicating a lapse in time and important climatic changes between karst formation and deposition of the fillings.

For detailed comments on the characteristics of filling profiles taken in large sinkholes on the eastern Niger plateaus cf. Sponholz (1992).

In a red (2,5 YR 5/8) palaeosoil that was studied in one of the closed depressions of

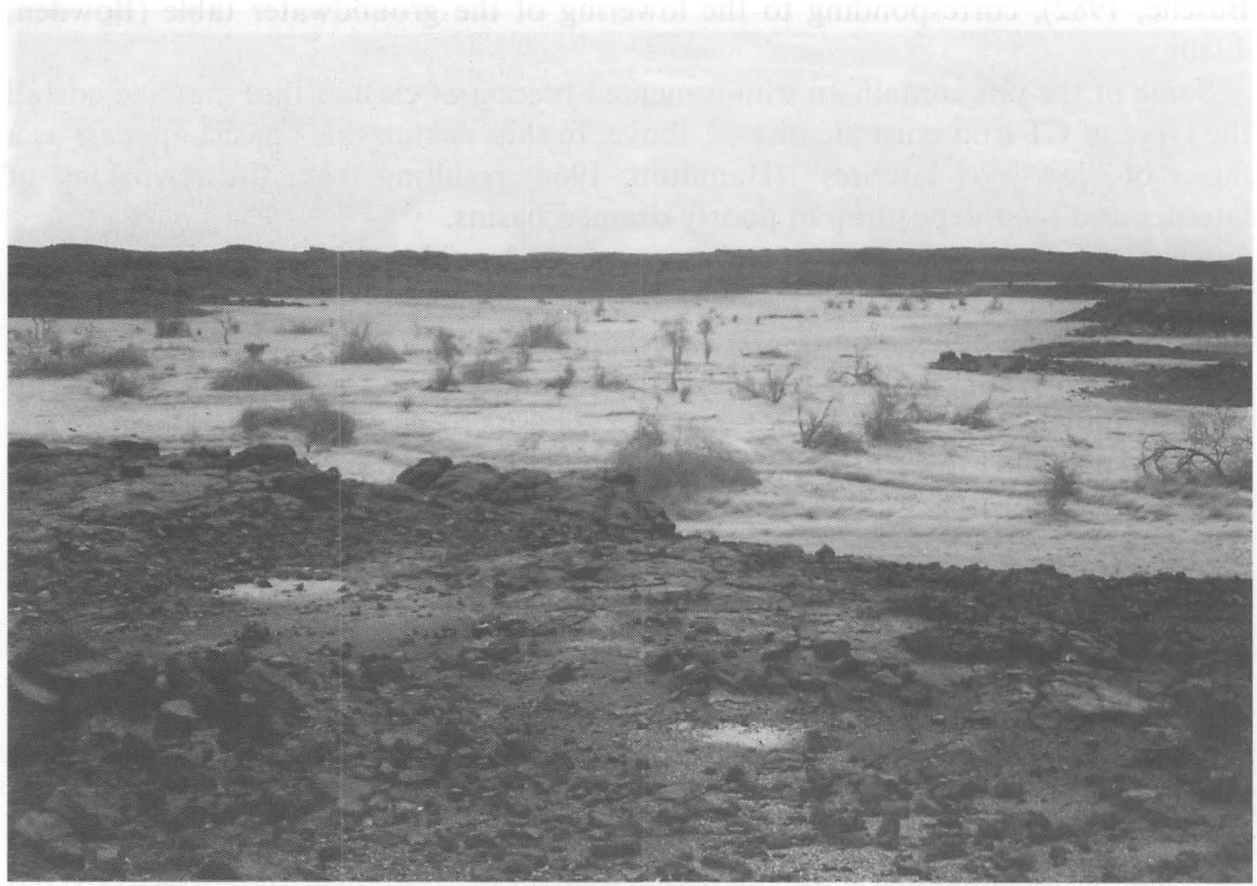

Fig. 3. Large sinkhole on the Termit plateau. The depression is filled with palaeosoils (see Fig. 4) and Holocene aeolian deposits. The depression is about $50 \times 150 \mathrm{~m}$ large. 
northern Termit (Termit-Nourounga), vertical columnar structures were found underlying a $15-25 \mathrm{~cm}$ deep cover of recent sands and a disturbed soil horizon (Figs. 4 and 5). The columnar structures are a maximum of $1 \mathrm{~cm}$ in diameter and a few centimeters long. The center may be a still open tubular void, but it may also be filled with fine loam and clay. The center is surrounded by concentric iron pisoids of about $1 \mathrm{~mm}$ in diameter. Similar pisoids float in the surrounding palaeosoil. X-ray analysis of the complete columnar structures (powder preparation) showed a composition of kaolinite, goethite and haematite. As seen in thin section, the kaolinite is most important in the central filling, whereas iron dominates in the pisoids. The columnar soil structures may derive from plant roots or animal burrows (Valeton, 1971). The pattern of the columns, the concentric, vermicular structure of their loamy filling, and the concentration of the pisoids in their outer parts indicate a degree of reworking that can most likely be attributed to animals, such as burrowing insects (cf. Schröder, 1929; Roubik, 1989). The grain size distribution changes in particular - in horizontal layers or around tubes - point towards termite activities (Lee and Wood 1971; Holt et al., 1980). A vegetal origin, however, might better explain the small diameter of the still open voids that do not seem adapted to animal habitation.

\subsection{Ferruginous stalactites in sandstone and iron crust karst caves}

Ferruginous stalactites have been precipitated in iron crust (Southern Termit

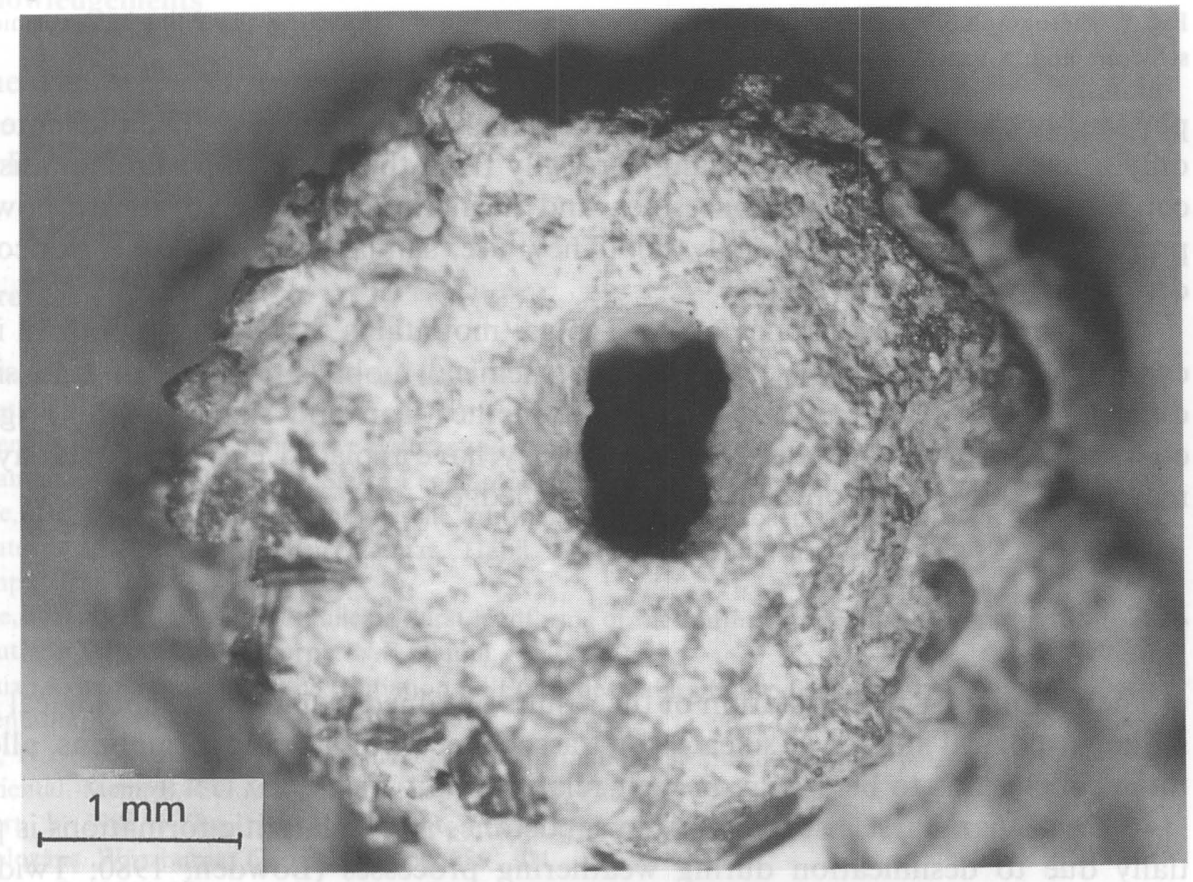

Fig. 4. Columnar structure sampled in the palaeosoil horizon at a depth of $15-25 \mathrm{~cm}$. The center is partly filled with fine loams and clays and surrounded by concentric iron concretions. 


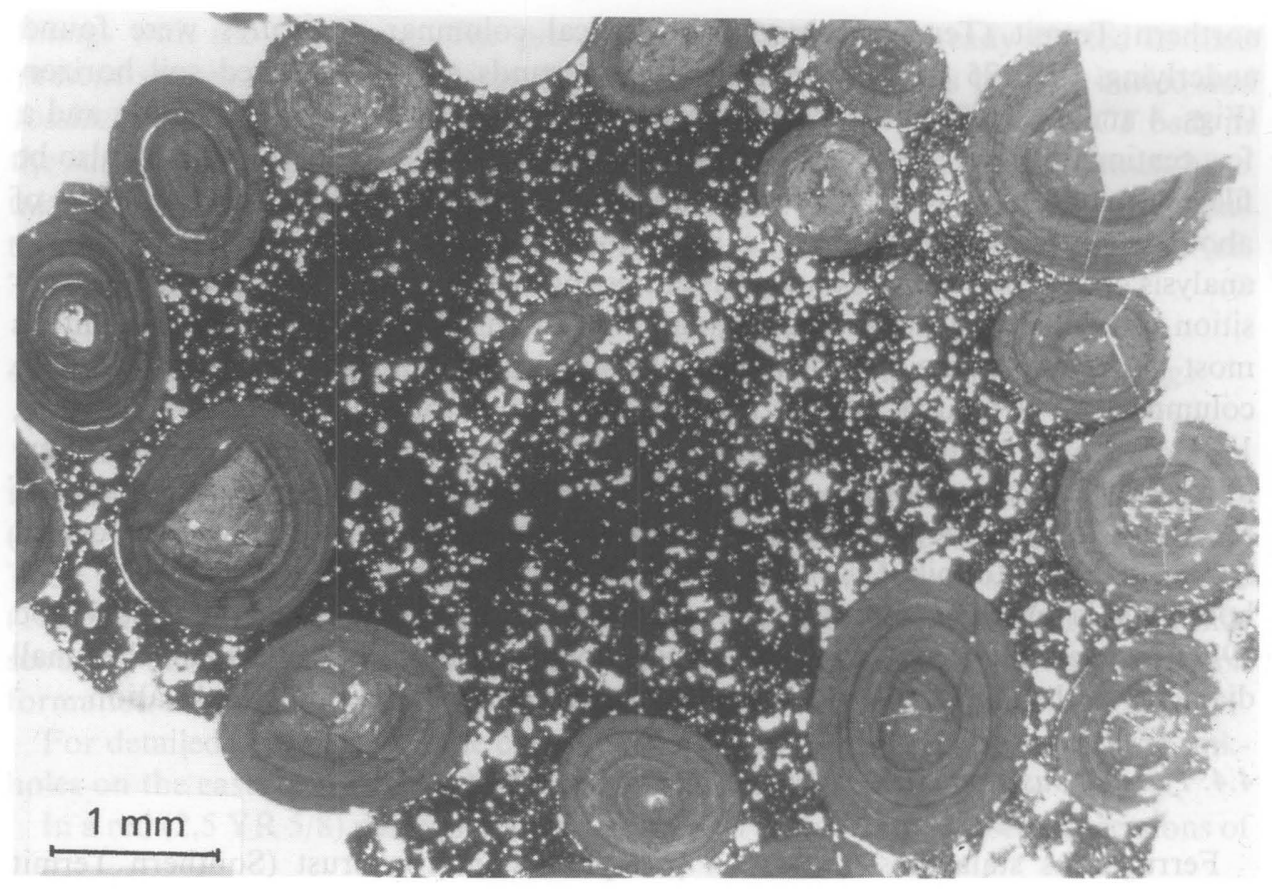

Fig. 5. Micrograph of a cross section of the sample shown in Fig. 4. The central clay filling has a vermicular structure and is firmly consolidated.

plateau) or sandstone karst caves (Southern Tchigai mountains). The stalactites of only a few millimeters' length hang vertically from the cave ceilings and consist of concentric layers of amorphous silica and haematite (X-ray analyses on powder preparations, thin-section analyses). They are similar to the "cave popcorn" described by Thrailkill (1976).

In the quartzitic sandstones of the Tchigai mountains that are very poor in iron compounds, the stalactites testify to the chemical mobilization of iron and silica during periods of intensive weathering. Whether iron and silica are the original component of the stalactites or whether they have replaced e.g. carbonate layers, may not be said at the present state of knowledge.

\section{Conclusions}

The preliminary interpretation of the results obtained from geomorphological and sedimentological studies of silicate karst associated with lateritic formations, allows three conclusions to be drawn on their relationship:

- Karst (parakarst, pseudokarst) in sandstones and in lateritic formations is partially due to desilification during weathering processes (Bowden, 1980; Twidale, 1987). At a later stage of formation not only silica but also iron compounds are mobilized by chemical action, and it is above all the mobilization of both of these 
materials that caused karst development in iron-rich sediments such as CT. Comparable analytical studies on sandstone karst development have also been made by the author (Sponholz, 1989).

- The relationship between the sandstone karst landforms and their lateritic fillings is very important for the chronology of geomorphological events (cf. 4.2). A similar chronology may be established for the iron crust karst of the Termit and Agadem plateaus and their lateritic fillings.

- The unconsolidated fillings of iron crust pits and sinkholes (cf. 4.1 and 4.3) probably date from the late Pleistocene and the Holocene. The uppermost aeolian deposits indicate an aridification of the climatic conditions since the mid-Holocene (chronology related to the results of geomorphological and palaeoenvironmental studies in the same region, e.g. Servant, 1983; Grunert, 1988; Völkel, 1989; Baumhauer, 1991; Schulz, 1991; Pomel and Schulz, 1992).

The karst in the sandstones and iron crusts of the Saharan plateaus and their different lateritic and non-lateritic fillings are very important for any groundwater modelling in the regions concerned. Also, the reconstruction of palaeovegetation patterns must take this karst into consideration because of its creation of specific edaphic situations.

\section{Acknowledgements}

The Deutsche Forschungsgemeinschaft is sincerely acknowledged for financial support. I thank the Centre de Géomorphologie du C.N.R.S, Caen/France for sample preparations.

\section{References}

Baumhauer, R., 1991. Palaeolakes in the south central Sahara - problems of palaeoclimatological interpretation. Hydrobiologia, 214: 347-357.

Bowden, D.J., 1980. Sub-laterite cave systems and other pseudo-karst phenomena in the humid tropics: The example of the Kasewe Hills, Sierra Leone. Z. Geomorph. N.F., 24/1: 77-90.

Busche, D., 1982. Die geomorphologische Entwicklung des westlichen Murzukbeckens, des DjadoPlateaus und des nördlichen Kaouar. Habil. Schr. Geograph. Inst. Univ. Würzburg, 2 Vols. (unpublished).

Busche, D. and Erbe, W., 1987. Silicate karst landforms of the southern Sahara (northeastern Niger and southern Libya). Z. Geomorph. N.F., Suppl., 64: 55-72.

Cailleux, A. and Tricart, J., 1963. Initiation à l'Etude des Sables et des Galets, Vol. 1. Centre de Documentation Universitaire, Paris, 369 pp.

Faure, H., 1966. Reconnaissance géologique des formations sédimentaires post-paléozoiques du Niger Oriental. Mem. B.R.G.M., 47. Editions B.R.G.M., Paris, 630 pp.

Grunert, J., 1988. Klima- und Landschaftsentwicklung in Ostniger während des Jungpleistozäns und Holozäns. Würzburger Geogr. Arb., 69: 289-304.

Hamilton, R., 1964. Microscopic studies of laterite formations. In: A. Jongerius (Editor), Soil Micromorphology. Elsevier, Amsterdam, pp. 277-278.

Holt, J.A., Coventry, R.J. and Sinclair, D.F., 1980. Some aspects of the biology and pedological signifi- 
cance of mound-building termites in a Red and Yellow Earth landscape near Charters Towers, North Queensland. Aust. J. Soil Res., 18: 97-109.

Lee, K.E. and Wood, T.G., 1971. Termites and Soils. London, 251 pp.

Müller, G., 1967. Methods in Sedimentary Petrology. Vol. 1. Schweizerbart, Stuttgart, 283 pp.

Pomel, S. and Schulz, E., 1992. Les sols des savanes anthropogènes du Cameroun. Würzburger Geograph. Arb., 84: 289-324.

Renault, P., 1953. Caractères généraux des grottes gréseuses du Sahara méridional. In: Actes du ler Congr. Internat. Spéléol., Paris, 2/1, pp. 275-289.

Roubik, D.W., 1989. Ecology and Natural History of Tropical Bees. Cambridge Univ. Press, Cambridge, $514 \mathrm{pp}$.

Schröder, Ch. (Editor), 1929. Handbuch der Entomologie, Vol. 2. Gustav-Fischer-Verlag, Jena.

Schulz, E., 1991. Paléoenvironnement dans le Sahara central pendant l'Holocène. Paleaoecol. Afr., 22: 191201.

Servant, M., 1983. Séquences continentales et variations climatiques: Evolution du Bassin du Tchad au Cénozoique Supérieur. Trav. Doc. O.R.S.T.O.M., 159, Paris, 348 pp.

Silvestru, E., 1990. Propositions pour une classification lithogénétique des formes karstiques et apparentées. Karstologia, 15: 55-57.

Sponholz, B., 1989. Karsterscheinungen in nichtkarbonatischen Gesteinen der östlichen Republik Niger. Würzburger Geogr. Arb., 75, 268 pp.

Sponholz, B., 1992. Karstverfüllungen in Ostniger. Würzburger Geogr. Arb., 84: 131-145.

Thrailkill, J., 1976. Speleothems. Dev. Sedimentol., 20: 73-86.

Twidale, C.R., 1987. Sinkholes (dolines) in lateritised sediments, Western Sturt Plateau, Northern Territory, Australia. Geomorphology, 1: 33-52.

Upton, G., 1983. Genesis of crabhole microrelief at Fowlers Gap Western South Wales. Catena, 10: 383392.

Valeton, I., 1971. Tubular fossils in the bauxites and the underlying sediments of Surinam and Guyana. Geol. Mijnbouw, 68: 263-279.

Völkel, J., 1989. Geomorphologische und pedologische Untersuchungen zum jungquartären Klimawandel in den Dünengebieten Ost-Nigers (Südsahara und Sahel). Bonner Geogr. Abh., 79, 258 pp. 